\title{
Effects of maternal artificial vocalization on hyperprolific lactating sows and piglets behavior
}

\author{
RENNAN H.R. MOREIRA ${ }^{1}$, RODRIGO F. DE OLIVEIRA ${ }^{2}$, JORGE Y.P. PALENCIA ${ }^{1}$, \\ MARINA A.G. LEMES ${ }^{1}$, MARILANE D. SILVA ${ }^{1}$, CESAR A.P. GARBOSSA ${ }^{3}$, MÁRVIO \\ L.T. DE ABREU ${ }^{1}$, GISELLE B. DE MOURA ${ }^{1}$ and RONY A. FERREIRA ${ }^{1}$
}

\begin{abstract}
${ }^{1}$ Departamento de Zootecnia, Universidade Federal de Lavras/UFLA, Avenida Sul, s/n, 37200-000 Lavras, MG, Brazil ${ }^{2}$ Departamento de Tecnologia, Faculdade de Ciências Agrárias e Veterinárias de Jaboticabal, Universidade Estadual Paulista Júlio de Mesquita Filho, Via de acesso Prof. Paulo Donato Castellane, s/n, 14884-900 Jaboticabal, SP, Brazil

${ }^{3}$ Departamento de Nutrição e Produção Animal, Faculdade de Medicina Veterinária e Zootecnia, Universidade de São Paulo, Avenida Duque de Caxias Norte, 225, Jardim Elite, 13635-900 Pirassununga, SP, Brazil
\end{abstract}

Manuscript received on April 11, 2018; accepted for publication on May 23, 2018

\begin{abstract}
The objective of this trial was to evaluate the behavioral patterns and performance of lactating sows and their litters under the effect of artificial vocalization. Twenty-eight sows and their litters were distributed in a completely randomized design in a $2 \times 2$ factorial scheme (artificial vocalization $\times$ lactation week). The behavior of the animals was monitored during 24 hours on the $7^{\text {th }}$ and $15^{\text {th }}$ days of lactation, analyzing the number, interval, and frequency of nursings. The body condition and performance of the sows were also evaluated. Artificial vocalization promoted higher frequencies of eating for sow and nursing for piglets $(\mathrm{P}$ $<0.05$ ), increased inactive sow behavior $(\mathrm{P}<0.05)$, and reduced sow alert in activity $(\mathrm{P}<0.05)$. The number and duration of suckling sessions at the $15^{\text {th }}$ day of lactation were reduced $(\mathrm{P}<0.05)$. The use of artificial vocalization did not affect the body condition or milk production of the lactating sows, or the performance of the litter during lactation $(\mathrm{P}>0.05)$. The use of maternal artificial vocalization during lactation of sows promoted greater lactation efficiency and longer rest time, favoring the sows' welfare.
\end{abstract}

Key words: behavior suckling, piglet, swine production, sow grunting, nursing, vocal communication.

\section{INTRODUCTION}

Swine production is a dynamic system with several factors that, in synergy, can advance the production efficiency of the herd, as well as improving the welfare of the animals, which consequently progress economic efficiency. The main factors in the animals' development are genetics, nutrition,

Correspondence to: Rony Antônio Ferreira

E-mail: rony@dzo.ufla.br environment, and the interaction among animals. This same awareness can be applied to the maternity environment, where sows farrow and nurse their piglets. With respect to this maternity environment, the indexes that most impact the production system are the number of piglets weaned, litter weight at weaning, and mortality.

For these indexes to be achieved, a quiet environment is required, as high frequency of noise, for example, may reduce milk production 
due to a communication failure between the sow and the litter during suckling (Algers and Jensen 1991), which could possibly affect the productive performance of the sows. The number, duration, and interval of suckling are of fundamental importance for the adequate development of piglets, since milk is the main food source for piglets during this period. However, recent literature on this topic has been only slightly explored, and further studies on nursing behavior are necessary, as the behavior pattern of sows may change during nursing. These changes occur due to constant genetic advancement, which results in females with a greater number of piglets per farrowing and at weaning, as well as females with lower body fat content; it is possible that these factors could alter both milk production and nursing behavior. The opposite is also true: the greater the stimulation nursings instead of feedings, the greater is the milk production. This is influenced by the size of the litter, number and duration of feedings, maternal characteristics (ability), and occurrence of stressors in the maternity environment.

Pigs have the ability to communicate through vocalization; approximately 40 language expressions among litter's members have been reported (Van Putten 2000). Sounds are capable of influencing animal behavior, and can be used as positive or negative reinforcement, which is related to animals' cognitive ability (Sarubbi 2011). Therefore, the use of artificial vocalization of sows may be able to modulate their nursing behavior. The emitted calls can provide information about the emotional state of an animal, and may reflect its psychological need in the absence of individuals who would normally be participating in its social life (Watts and Stookey 2000).

Because of the lack of recent research using continuous recordings of pig vocalization during confinement time, and the lack of evaluation of welfare issues in a productive environment, studies on animal bioacoustics are characterized as a recent and innovative study with respect to production animals. This is a new global trend related to international requirements, which are increasingly being related to good animal welfare practices (Borges 2013). The aim of the study was to evaluate the behavioral pattern of lactating sows and their litters using artificial vocalization of sows.

\section{MATERIALS AND METHODS}

\section{FACILITIES}

The experiment was carried out in two maternity barns, located in the municipality of Oliveira, Minas Gerais, Brazil. The farrowing crates instead of maternity stalls had a nipple-type drinker and specific feeders for sows and piglets, with $2 / 3$ slatted floor sand creep area. Heating was provided to the piglets only during the first week of life.

\section{ANIMALS, DIET, AND EXPERIMENTAL DESIGN}

The study was approved by the Bioethics Committee of the Universidade Federal de Lavras, filled under registration 70/14. The experiment was conducted using 28 sows and their litters. The sows from the same genetic pattern (DB-90) between the $3^{\text {rd }}$ and $5^{\text {th }}$ parity, were selected from a reproductive history of 12 to 13 piglets born alive. The sow of each treatment were allocated in different barns. The farrowing occurred on the same day. In this way, the design was completely randomized in a $2 \times 2$ factorial scheme (artificial vocalization and lactation week). The experimental unit comprised sows with similar body condition and their respective litters. Only the females received feed during the experiment, according to the formula adopted by the farm, based on corn and soybean meal.

\section{EMISSION AND SOUND CHARACTERIZATION}

Based on preliminary observations of our research group made to determine the nursing interval during the $1^{\text {st }}, 2^{\text {nd }}$, and $3^{\text {rd }}$ week of lactation, the 
interval was reduced in $40 \%$ and used as reference for intervals between the sound emission during the experiment. Being played for two minutes and a silence period of $14.5,17.6$, and 19.6 minutes for the first, second, and third week, respectively. During the experimental period, artificial vocalization was performed daily from 6:00 p.m. to 6:00 a.m., to avoid possible interference during the daytime period of greater sound pressure on the farm. The lights remained on during the period.

For sound emission, a sound amplifier (Ciclotron Wattsom Cube 60 guitar amplifier, São Paulo, Brazil) was installed in one of the rooms, 6 meters from the nearest crate and 20 meters from the most distant, and at a height of 3 meters from the floor. Control sows were housed in another barn 50 meters apart. No sound of the artificial vocalization was possible to hear in the control barn.

The artificial vocalization used as a stimulus for the females was obtained from a video (https:// www.youtube.com/watch?v=-DBcp6YGi6k), where the sows vocalized for 2 minutes, about 30 times during the nursing of the piglets. The sound was characterized as bass by Sound Forge Pro $11.0^{\circledR}$ software.

\section{BEHAVIORAL PARAMETERS}

The behaviors of the sows and their respective litters were monitored for 24 hours starting at 6:00 am on the $7^{\text {th }}$ and $15^{\text {th }}$ days of lactation. The images were captured by cameras and stored on a DVD recorder (NEOcam, Model H.264DVR, São Paulo, Brazil). The behavioral variables analyzed were number and interval of suckling. Suckling was considered to have commenced when half of the litter started the act with teat in the mouth.

The behaviors evaluated for the sows were feed and visits to the water fountain, stereotyped behavior, biting, inactivity, and inactive alertness were recorded as suggested by Pandorfi et al. (2006).

\section{MEASUREMENTS OF THE SOWS AND LITTERS}

The feed was given to the sows in form of mash, in time periods. The daily amount offered during lactation was determined according to the voluntary consumption of each sow. Daily records of consumption and feed waste were evaluated; for this measurement, the first daily supply began at 7:00 a.m., and the leftovers and waste were weighed. The next day's supply was always offered at the same time. Water was supplied ad libitum throughout the experimental period. The piglets did not receive feed throughout the sows' lactation period.

Body weight, back fat thickness, and loin depth were used as parameters for the evaluation of body condition, according to the methodology of Souza (2011). On the second day after farrowing and at weaning, the sows and litters were weighed individually. The litters were equal in weight and number of piglets after delivery (12 or 13), and the piglets were assisted to guarantee the first suckling of colostrum. To maintain a microclimate, within the piglets' thermal comfort zone, an incandescent lamp was used inside the creep for each farrowing crate.

The milk yield of the sows was estimated by an equation suggested by Noblet and Etianne (1989).

\section{ENVIRONMENTAL MONITORING}

To characterize the environment of the farrowing rooms, a temperature and relative humidity sensor with a data logger function per room was used (Instrutherm, HT-500, São Paulo, Brazil), installed at a height of 1 meter from the females, which collected the data every $10 \mathrm{~min}$ throughout the experimental period.

\section{STATISTICAL ANALYSES}

Statistical analyzes were performed using the SAS statistical package (9.0). All data were submitted to normality analysis by the Shapiro-Wilk test at the $5 \%$ probability level. The data that did not present 
normal distribution were normalized through PROC RANK of the SAS statistical package (9.0). The data were compared by the F test. Data that were not normalized after transformation were compared by the Kruskal-Wallis test at the 5\% probability level.

\section{RESULTS}

\section{ENVIRONMENTAL MONITORING}

The average values of temperature $\left({ }^{\circ} \mathrm{C}\right)$ and relative humidity (\%) are shown in Figure 1.

\section{BEHAVIORAL PARAMETERS}

The use of artificial vocalization did not change the behaviors of drinking, stereotyping, inactive alertness, biting, and rooting on the $7^{\text {th }}$ day of lactation $(\mathrm{P}>0.05)$. However, vocal stimulus promoted a higher frequency of eating behavior (mean of 18 minutes more per day) $(\mathrm{P}<0.05)$ and nursing (about 66 minutes more per day); however, the sowshad less inactive time $(\mathrm{P}<0.05)$ (Table I).

At the $15^{\text {th }}$ day of lactation, the use of artificial vocalization did not change the behaviors of drinking, eating, stereotyping, biting, and rooting $(\mathrm{P}>0.05)$ (Table II). However, it promoted an increase in inactive behavior (mean of 161 minutes more per day) $(\mathrm{P}<0.05)$ and reduction of alert inactivity (mean of 127 minutes less per day) ( $P$ $<0.05)$, as well as less time dedicated to nursing (mean of 31 minutes fewer per day).

Artificial vocalization did not change the number, duration, and suckling interval on the seventh day of nursing ( $\mathrm{P}>0.05)$ (Table III). However, there was a reduction in the number (8.66 times) and duration (0.9 minutes) of suckling on the $15^{\text {th }}$ day of nursing $(\mathrm{P}<0.05)$, resulting in an increase in suckling of about 20 minutes $(\mathrm{P}<0.05)$.

\section{PERFORMANCE OF LACTATING SOWS AND LITTERS}

The use of artificial vocalization did not affect body condition, milk yield of lactation sows, or litter performance during lactation (Tables IV and V).

\section{DISCUSSION}

All sows from the experiment were not in environmentally, especially during the period from 10 am to $7 \mathrm{pm}$, when the ambient temperature was $30 \%$ higher than recommended, which is between $16^{\circ} \mathrm{C}$ and $22^{\circ} \mathrm{C}$ (Bragança et al. 1998).

It is likely that the artificially emitted sound was audible for both the sows and for the piglets, since pigs often detect sounds pressure between 40 and 40,000 Hz (Heffer and Heffer 1992). Additionally, the sound reproduced for 2 minutes agreed with the

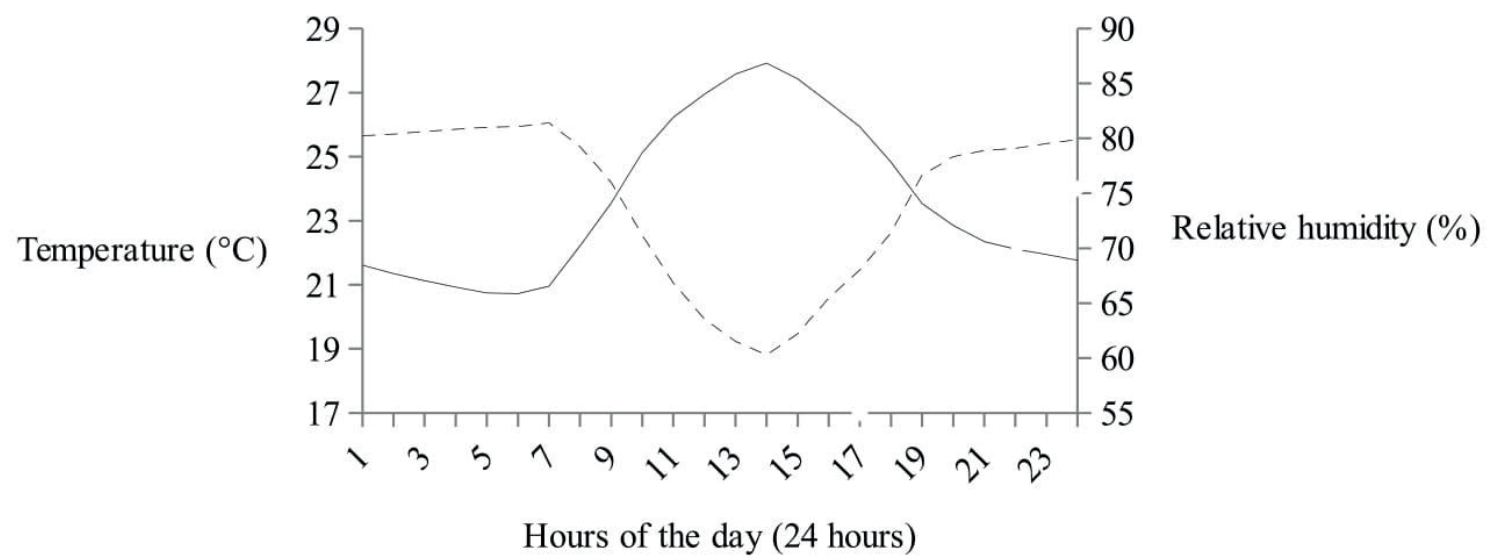

Figure 1 - Temperature (continuous line) and relative humidity of the air (dashed line) verified in the maternity room. 
sonorous pattern of the swine at the time of milk ejection according to Whittemore and Fraser (1974), Fraser (1980), and Algers et al. (1985).

Some factors may modulate the behavior of pigs. It is possible that the vocalization emitted in this trial transmitted information to the brain and activated brain regions responsible for the greater intake of food by the sow on the $7^{\text {th }}$ day of lactation (Oliveira Junior et al. 2011). Being more sated, the sow spent more time nursing the piglets. However, these behavioral changes resulting from artificial vocalization did not affect the number, duration, and interval of nursing during the first week of lactation. It is important to consider that piglets prefer the vocalizations produced by their own mothers in comparison with those produced by another sow or artificial sound (Puppe et al. 2003), however, artificial vocalization can modulate the behavior of the sow. This corroborates with the findings of Oliveira Junior et al. (2011), demonstrating that sows spent more than $80 \%$ of their time each day nursing or in a lying position.

Newberry and Wood Gush (1984) and Martins et al. (2008) suggested that lactating sows respond to each other's vocalizations. In a study conducted by Šilerová et al. (2013), it was verified that sows without acoustic or visual contact did not synchronize nursing. The authors found that auditory communication is crucial for the timing of nursing. Other studies have indicated that this synchronization may result in increased frequency of nursing (Spinka et al. 2002, Illmann et al. 2002, 2005).

Changes in cognitive and motor activities in pigs were observed by Jonge et al. (2008) and by Moreira (2012) when stimulated by music, which were positive indicators of welfare.

As lactational age advances, some changes in behavior may be related to the duration of suckling, which becomes shorter as the piglets grow larger (Corassa et al. 2014).

At 15 days of lactation, females who had artificial vocalization spent less time nursing, allowing for a longer rest period (more inactive and less inactive alertness), in an intensive husbandry, this could mean moments of greater tranquility, thus increasing their welfare. In this period, artificial vocalization, despite reducing the number and duration of nursings, did not compromise the performance of the litters, and it may be suggested that the females had better lactation efficiency. Our results are similar to those reported by Fraser and

TABLE I

Behavior average daily frequencies (\%) of sows due to the use of artificial vocalization or not at 7 days of lactation.

\begin{tabular}{|c|c|c|c|c|c|}
\hline Variables & Control & Vocalization & $\mathbf{P}$ & Standard error & $C V^{1}$ \\
\hline Drinking & 0.17 & 0.52 & 0.053 & 0.206 & 103.28 \\
\hline Eating & 0.26 & 1.48 & 0.032 & 0.472 & 147.52 \\
\hline Stereotyped & 0.00 & 0.00 & 1.000 & 0.087 & 0.00 \\
\hline Inactive & 80.64 & 73.87 & 0.010 & 1.812 & 6.89 \\
\hline Inactive alertness & 4.86 & 5.04 & 0.243 & 1.344 & 65.20 \\
\hline Nursing & 14.07 & 18.66 & 0.004 & 2.345 & 20.96 \\
\hline Biting & 0.00 & 0.00 & 1.000 & 0.000 & 0.000 \\
\hline Rooting & 0.00 & 0.43 & 0.064 & 1.802 & 253.85 \\
\hline Total \% & 100 & 100 & & & \\
\hline
\end{tabular}

${ }^{1} \mathrm{CV}$ : Coefficient of variation (\%). The parameters were compared by the Kruskal-Wallis test at the 5\% probability level. 
TABLE II

Behavior average daily frequencies (\%) of sows due to the use of artificial vocalization or not at 15 days of lactation.

\begin{tabular}{lccccc}
\hline \multicolumn{1}{c}{ Variables } & Control & Vocalization & P & Standard error & $\mathbf{C V}^{\mathbf{1}}$ \\
\hline Drinking & 0.09 & 0.78 & 0.096 & 0.445 & 192.70 \\
Eating & 1.13 & 0.26 & 0.077 & 0.987 & 141.42 \\
Stereotyped & 0.00 & 0.00 & 1.000 & 0.142 & 0.00 \\
Inactive & 72.83 & 84.03 & 0.001 & 2.798 & 9.61 \\
Inactive alertness & 12.07 & 3.21 & 0.001 & 2.673 & 84.57 \\
Nursing & 13.89 & 11.72 & 0.014 & 0.557 & 13.57 \\
Biting & 0.00 & 0.00 & 1.000 & 0.000 & 0.00 \\
Rooting & 0.00 & 0.00 & 1.000 & 0.000 & 0.00 \\
Total \% & 100 & 100 & & \\
\hline
\end{tabular}

${ }^{1} \mathrm{CV}$ : Coefficient of variation (\%). The parameters were compared by the Kruskal-Wallis test at the $5 \%$ level.

TABLE III

Behavior of suckling piglets due to artificial vocalization.

\begin{tabular}{|c|c|c|c|c|c|}
\hline Suckling & Control & Vocalization & $\mathbf{P}$ & $\begin{array}{c}\text { Standard } \\
\text { error }\end{array}$ & $\mathrm{CV}^{1}$ \\
\hline \multicolumn{6}{|l|}{ Number (n) } \\
\hline $7^{\text {th }}$ day & 36.29 & 37.63 & 0.388 & 1.149 & 7.78 \\
\hline $15^{\text {th }}$ day & $33.29^{\mathrm{a}}$ & $24.63^{\mathrm{b}}$ & 0.001 & 0.981 & 18.68 \\
\hline \multicolumn{6}{|l|}{ Duration (min) } \\
\hline $7^{\text {th }}$ day & 5.29 & 6.26 & 0.100 & 0.359 & 15.20 \\
\hline $15^{\text {th }}$ day & $5.83^{\mathrm{a}}$ & $4.93^{b}$ & 0.003 & 0.190 & 11.42 \\
\hline \multicolumn{6}{|l|}{ Interval (min) } \\
\hline $7^{\text {th }}$ day & 34.49 & 31.94 & 0.081 & 1.038 & 8.57 \\
\hline $15^{\text {th }}$ day & $37.26^{\mathrm{a}}$ & $56.80^{\mathrm{b}}$ & 0.001 & 3.401 & 26.02 \\
\hline
\end{tabular}

${ }^{1} \mathrm{CV}$ : Coefficient of variation (\%). Means followed by different letters in the line differ by the F test.

Rushen (1991), who reported that nursing occurred at intervals of 40 to 60 minutes, and by Weary et al. (2002), who observed within the first days after farrowing, that sows can nurse $30 \mathrm{~min}$ a day.

It has been demonstrated in sheep and humans that newborns develop a preference for their mother's voice (Poindron and Carrick 1976, Decasper and Fifer 1980). According to a study by Walser (1986), 88\% of newly born Clun Forest lamb responded exclusively to their mother's voice. It is quite possible that synchronization of nursing is impaired, at least during the first days of life, if piglets at birth are exposed to the grunts of other sows, making it more difficult to identify the voice of their own mother (Algers 1993). Thus, it is probable that artificial vocalization had effect on the mother, if it made synchronization of feedings possible.

Once the functional structure for lactation is formed, the limiting factor for milk production and maintenance of adequate body condition comes from nutritional contribution to the mammary gland, arising from the sows' body reserves and diet (Hurley 2001). Since the sows did not have significant differences in feed intake and body condition, it was expected that there would also be no difference in milk production, since the only two sources of nutrients for its production are diet 
TABLE IV

Performance and body condition of sows due to the use of artificial vocalization or not during lactation.

\begin{tabular}{|c|c|c|c|c|c|}
\hline Variables & Control & Vocalization & $\mathbf{P}$ & $\begin{array}{c}\text { Standard } \\
\text { error }\end{array}$ & $\mathbf{C V}^{1}$ \\
\hline Number of sows & 13 & 15 & & & \\
\hline $\begin{array}{l}\text { Average daily feed } \\
\text { intake }(\mathrm{kg})\end{array}$ & 6.472 & 6.244 & 0.103 & 0.055 & 4.71 \\
\hline \multicolumn{6}{|l|}{$\begin{array}{l}\text { Weight of sows } \\
(\mathrm{kg})\end{array}$} \\
\hline 2 days & 259.00 & 267.73 & 0.358 & 4.511 & 9.11 \\
\hline 20 days & 246.00 & 256.53 & 0.285 & 4.635 & 9.91 \\
\hline \multicolumn{6}{|l|}{$\begin{array}{l}\text { Weight loss of the } \\
\text { sows }(\mathrm{kg})\end{array}$} \\
\hline 2 to 20 days & 13.00 & 11.20 & 0.892 & 0.022 & 276.43 \\
\hline \multicolumn{6}{|l|}{$\begin{array}{l}\text { Weight loss of the } \\
\text { sows }(\%)\end{array}$} \\
\hline 2 to 20 days & 4.94 & 3.02 & 0.686 & 2.213 & 307.21 \\
\hline $\begin{array}{l}\text { Loin depth at } 2 \\
\text { days }(\mathrm{mm})\end{array}$ & 47.38 & 42.63 & 0.203 & 1.297 & 21.27 \\
\hline $\begin{array}{l}\text { Loin depth at } 20 \\
\text { days }(\mathrm{mm})\end{array}$ & 58.21 & 53.46 & 0.298 & 1.728 & 20.82 \\
\hline $\begin{array}{l}\text { Backfat thickness } \\
\text { at } 2 \text { days }(\mathrm{mm})\end{array}$ & 12.55 & 10.61 & 0.223 & 0.542 & 31.49 \\
\hline $\begin{array}{l}\text { Backfat thickness } \\
\text { at } 20 \text { days }(\mathrm{mm})\end{array}$ & 10.02 & 8.41 & 0.160 & 0.409 & 29.50 \\
\hline $\begin{array}{l}\text { Milkyield (kg } \\
\text { day }^{-1} \text { ) }\end{array}$ & 8.16 & 7.49 & 0.335 & 0.338 & 22.25 \\
\hline
\end{tabular}

${ }^{1} \mathrm{CV}$ : Coefficient of variation (\%).

TABLE V

Live weight and daily weight gain of piglets due to the use of artificial vocalization of lactating sows.

\begin{tabular}{|c|c|c|c|c|c|}
\hline Variables & Control & Vocalization & $\mathbf{P}$ & $\begin{array}{c}\text { Standard } \\
\text { error }\end{array}$ & $C V^{1}(\%)$ \\
\hline Number of litters & 12 & 15 & & & \\
\hline Piglets/sow at $2^{\text {nd }}$ day & 12.58 & 11.86 & 0.058 & 0.197 & 8.04 \\
\hline Piglets/sow at $20^{\text {th }}$ day & 10.75 & 9.86 & 0.282 & 0.414 & 20.16 \\
\hline Weight at $2^{\text {nd }}$ day $(\mathrm{kg})$ & 1.384 & 1.501 & 0.230 & 46.401 & 16.96 \\
\hline Weight at $20^{\text {th }}$ day $(\mathrm{kg})$ & 5.804 & 5.864 & 0.852 & 149.970 & 13.60 \\
\hline ADG 2 to 20 days (g) & 210.5 & 207.7 & 0.839 & 6.310 & 15.96 \\
\hline
\end{tabular}

${ }^{1} \mathrm{CV}$ : Coefficient of variation (\%). ADG: Average daily gain.

and body reserves. The performances of the litters are justified by the performance of the lactating sows who received similar husbandry conditions, however, the animals that were stimulated with artificial vocalization led to an improvement in the sows' behavior, indicating improved welfare.

\section{CONCLUSION}

The use of maternal artificial vocalization during lactation of sows promoted greater lactation efficiency and longer rest time, favoring their welfare. 


\section{ACKNOWLEDGMENTS}

We thank Fazenda São Paulo for their support on the trial. This study was financed in part by the Coordenação de Aperfeiçoamento de Pessoal de Nível Superior (CAPES), FinanceCode 001.

\section{REFERENCES}

ALGERS B. 1993. Nursing in pigs: Communicating needs and distributing resources. J Anim Sci 71: 2826-2831.

ALGERS B AND JENSEN P. 1985. Communication during suckling in the domestic pig. Effects of continuous noise. Appl Anim Behav Sci 14: 49-61.

ALGERS B AND JENSEN P. 1991. Teat stimulation and milk production during early lactation in sows: effects of continuous noise. Can J Anim Sci 71: 51-60.

BORGES MG. 2013. Vocalização de suínos em grupo sob diferentes condições térmicas. Tese de Doutorado, Universidade de São Paulo, 91 p.

BRAGANÇA MM, MOUNIER M AND PRUNIER A. 1998. Does feed restriction mimic the effects of increased ambient temperature in lactating sows? J Anim Sci 76: 2017-2024.

CORASSA A, DAL MAGROTR, KOMIYAMA CM, MOREIRA PSA, BALLERINI K, BALLERIN IN AND PEREIRA TL. 2014. Comportamento e parâmetros fisiológicos de porcas em lactação na transição CerradoAmazônia. Com Sci 5: 286-294.

DECASPER AJ AND FIFER WP. 1980. On human bonding: newborns prefer their mother's voices. Science 208: 11741176.

FRASER D. 1980. A review of the behavioural mechanism of milk ejection of the domestic pig. Appl Anim Ethol 6: 247-255.

FRASER D AND RUSHEN J. 1991. Colostrum intake by newborn piglets. J Anim Sci 2: 1-13.

HEFFER HE AND HEFFER RS. 1992. Auditory Percepetion. In: Phillips $\mathrm{C}$ and Piggins D (Eds), Farm Animals and the Environment. CAB International, Wallingford, UK, p. 159-184.

HURLEY WL. 2001. Mammary gland growth in the lacting sow. Livest Prod Sci 70: 149-157.

ILLMANN G, POKORNÁ Z AND SPINKA M. 2005. Nursing synchronization and milk ejection failure as maternal strategies to reduce allosuckling in pair-housed sows (Sus scrofa domestica). Ethology 111: 652-668.

ILLMANN G, SMAZALOVÁ Z AND SPINKA M. 2002. Why there is a synchronization in nursings bouts in lactating sows? In: Koene PATSC (Ed), Proceedings of the $36^{\text {th }}$ International Congress of the ISAE. Egmondaan Zee, the Netherlands, 2002. Wageningen, the Netherlands, p. 68.
JONGE HF, BOLEIJ H, BAARS AM, DUDINK S AND SPRUIJT BM. 2008. Music during play-time: Using context conditioning as a tool to improve welfare in piglets. Appl Anim Behav Sci 15: 138-148.

MARTINS TDD, COSTA AN, SILVA JHV, VALENÇA RMB AND LUDKE JV. 2008. Postura e comportamento lactacional de matrizes suínas mantidas sob condições de temperatura ambiente elevada. Biotemas 21: 137-145.

MOREIRA SV. 2012. Neuromusicoterapia no Brasil: aspectos terapêuticos na reabilitação neurológica. R Bras Music 12: 18-26.

NEWBERRY RC AND WOOD-GUSH DGM. 1984. The Suckling behavior of domestic pigs in semi-natural environment. Behav 95: 11-25.

NOBLET J AND ETIANNE M. 1989. Estimation of sow milk nutrient output. J Anim Sci 67: 3352-3359.

OLIVEIRA JÚNIOR GM, DE FERREIRA AS, OLIVEIRA RFM, SILVA BAN, FIGUEIREDO EM AND SANTOS M. 2011. Behaviour and performance of lactating sows housed in different types of farrowing rooms during summer. Livest Sci 141: 194-201.

PANDORFI H, DA SILVA IJO, CARVALHO JL AND PIEDADE SMS. 2006. Estudo do comportamento bioclimático de matrizes suínas alojadas em baias individuais e coletivas, com ênfase no bem-estar animal na fase de gestação. Eng Rural 17: 1-10.

POINDRON PAND CARRICK MJ. 1976. Hearing recognition of the lamb by its mother. Anim Behav 24: 600-602.

PUPPE B, SCHÖN PC, TUCHSCHERER A AND MANTEUFFEL G. 2003. The influence of domestic piglets (Sus scrofa) age and test experience on the preference for the replayed maternal nursing vocalization in a modified open- field test. Acta Ethol 5: 123-443.

SARUBBI J. 2011. Bem-estar animal não se restringe às instalações e equipamentos: o uso de novas tecnologias. In: Fórum Integral de Suinocultura: Teoria e Prática do Bem-Estar Animal na Produção de Suínos. Curitiba, Anais, p. 36-50.

ŠILEROVÁ J, ŠPINKA M AND NEUHAUSEROVÁ K. 2013. Nursing behaviour in lactating sows kept in isolation, in acoustic and visual contact. Appl Anim Beahav Sci 143: 40-45.

SOUZA GHC. 2011. Níveis de ractopamina em dietas para suínos em terminação. Dissertação de Mestrado em Zootecnia, Universidade Federal dos Vales do Jequitinhonha e Mucuri, Diamantina, 43 p. (Unpublished data).

SPINKA M, GONYOU H ANDLI Y. 2002. Nursing sychronization and milk ejection success in lactating sows: don't suckle your babies alone. In: Koene PATSC (Ed), Proceedings of the $36^{\text {th }}$ International Congress of the ISAE. Egmondaan Zee, the Netherlands, 2002. Wageningen, the Netherlands, p. 67. 
VAN PUTTEN G. 2000. An ethological definition of animal welfare with special emphasis on pig behaviour. Proceedings of the Second NAHWOA Workshop, p. 165.

WALSER ES. 1986. How early can piglets recognise their sow's voice? Appl Anim Behav Sci 15: 177-187.

WATTS JM AND STOOKEY JM. 2000. Vocal behaviour in cattle: the animal's commentary on its biological processes and welfare. Appl Anim Beahav Sci 67: 15-33.
WEARY DM, PAJOR EA, BONENFANT M, FRASER D AND KRAMER DL. 2002. Alternative housing for sows and litters. Effects of sow-controlled housing combined with a communal piglet area on pre- and post-weaning behaviour and performance. Appl Anim Behav Sci 76: 279-290.

WHITTEMORE CT AND FRASER D. 1974. The nursing and suckling behavior and milk ejection. Br Vet J 130: 346-356. 